\begin{tabular}{|c|c|}
\hline & Volume \& Issues Obtainable at The Women University Multan \\
Annals of Social Sciences and Perspective \\
ISSN: 2707-7063, Volume 2, No.1 June 2021
\end{tabular}

\title{
Review: Food Price Fluctuations and Its Influence on Global Food Market
}

\author{
Ifra Chaudhry', Raheel Suleman ${ }^{2}$, Adrish Bhatti ${ }^{3}$, Inam Ullah ${ }^{4}$
}

\begin{abstract}
${ }^{1}$ Institute of Food Science \& Nutrition, Bahauddin Zakariya University, Multan Pakistan
${ }^{2}$ Department of Food Science and Nutrition, Times Institute Multan, Pakistan

${ }^{3}$ Department of Business Administration, Times Institute Multan, Pakistan

${ }^{4}$ Department of Food Science and Technology, University of Haripur, KPK Pakistan
\end{abstract}

\begin{tabular}{|c|c|}
\hline \multicolumn{2}{|c|}{ ARTICLE DETAILS } \\
\hline \multicolumn{2}{|c|}{ History: } \\
\hline Received: & February 22, 2021 \\
\hline Review: & June 28,2021 \\
\hline Accepted: & June 28,2021 \\
\hline Available C & : June 30, 2021 \\
\hline
\end{tabular}

\section{Keywords:}

Price fluctuation, Influence, Global Market.

\section{ABSTRACT}

Food price fluctuation is a multifarious problem in food marketing. Food price fluctuations have a huge effect on the vulnerable. Food security is considered at three levels (household, national and international levels). Food supply, safety, physical and financial accessibility, and food utilization are the four pillars of food security. Since 2006-2007, the costs of most food products in Pakistan have risen by more than 100 percent. Consumption patterns, income, market and stockholding are the main causes of increased food prices. Maternal and child nutrition is affected due to price fluctuation at the individual level. Short term and long-term police are important to improve food productivity by enhancing the agricultural system. The main focus of the study is to identify the effects of price fluctuations on poor pregnant women's diet specifically in Pakistan and then on the children. If a mother is malnourished or micronutrient deficient then the child will also be deficient in that specific nutrient and deficiency will run in families. Hence our purpose is to find out these deficiencies in Pakistan and better implementation of policies.

(C) 2021 The Authors, Published by WUM. This is an Open Access Article under the Creative Common Attribution Non Commercial 4.0

Corresponding author email address: drraheelsuleman@t.edu.pk

\section{Introduction}

Price fluctuation is a serious problem. When combining with other factors, it brings serious consequences for the most vulnerable. Farmers think that high prices are in the favor but the reality is the opposite. Inflation brings problems for the poor and middle class. The increase in the price of goods also impacts the farmers and they suffer. On the other hand, capital flows are risky because farmers as well as other food supply chain participants could lose their assets if prices fall. 
'Market fundamentals' are said to be the most important reason for price fluctuation. When Demand outruns the supply then it leads to an increase in prices. Other most eminent factors that contribute to inflation are the loss of biodiversity, Climate change, aquifers and depleted soils. Food production has increased to maximum in recent years as it was never as high as it is today.

The sudden fluctuation in prices is not only damaging to consumers but also affects producers. It has been seen that poor farmers don't have enough money to cope with these changes. So, it results in compromised investments and it surely affects crop production.

Formers are facing severe problems due to increased prices in the developing countries and these increased prices are the results of non-food factors which ultimately effects everything. The price of essentials like transport, fuel, fertilizers, rent kerosene and agricultural related products, has increased recently. So, the transporter and people related to the industry are facing higher transportation costs and to lower their burden they transfer this cost to farmers.

\subsection{Global Food Price Trends}

Inflation or deflation in food prices has serious impacts on the poor. It is obvious that some families benefit from higher prices and some are negatively affected due to over-pricing but it depends on a different reason such as which one is the seller and who is the buyer. It also depends on their income and rich households find it easy to adjust even in inflation. Some Low-income households usually spend a large portion of their capital and income on food items. It increases vulnerability to rising inflation. In many countries, Policymakers try to contain the food prices for their people and they also respond to food price changes, especially increase in prices by making effective policies to contain the prices in their country. Foreign companies were able to do this by limiting exports. On the other hand, lowering import barriers help importers.
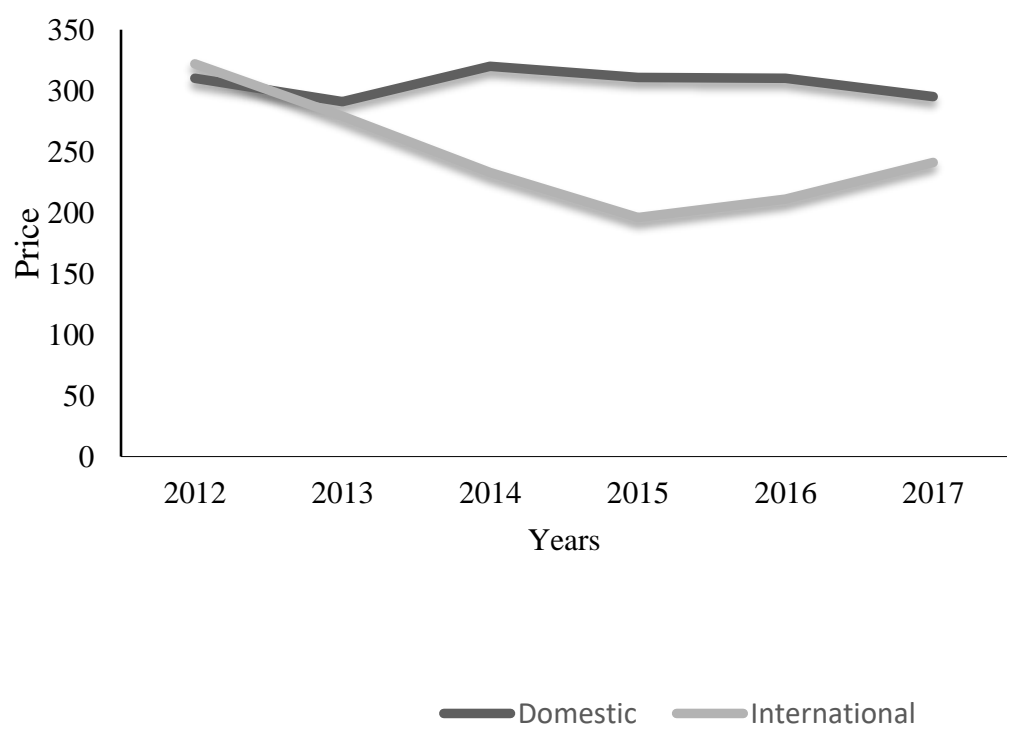

Sources: Index Mundi, State Bank of Pakistan, Punjab Food Department

Figure 1: Wheat prices showed between domestic and international market over the years from 2012-2017.

We have to consider two more factors here, as more time is given to the markets to adopt the change. First, changes in food prices may change the factor go back. After the first, changes 
in yield patterns of poor households may also occur. The factor that go back is the factor that shows the wage rate for untrained labor these households provide outside their farms. The influence on labor costs is becoming more and more significant when the commodity is:

a) Extremely labor exhaustive.

b) The large share of yield, e.g. rice in Bangladesh.

c) Contains huge use of intermediary inputs.

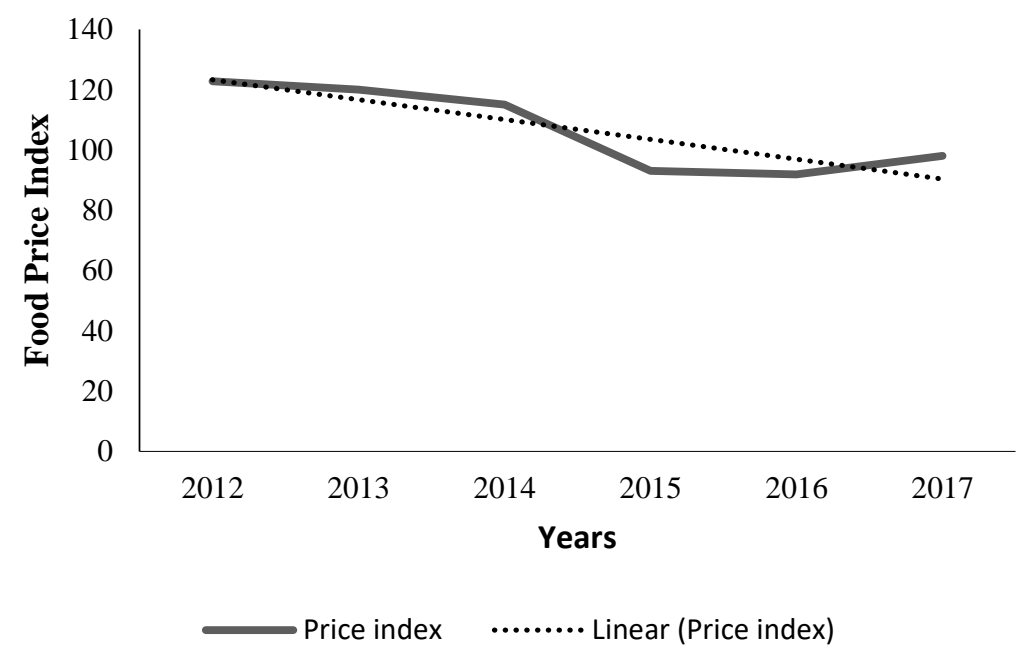

Figure 2: Global food price index comparison with general price index from 2012 to 2017 (FAO,2018).

\subsection{Global Food Price Index and Fluctuations}

In November 2020, (FFPI) averaged 105.0 figures, 4.0 figures (3.9\%) up from October and 6.4 figures $(6.5 \%)$ greater than its value from the previous year. Since July 2012 the rise in November was not only the largest mark on monthly rises, it also contributed to the graph reach its maximum amount since December 2014. Most of the FFPI thread increased in November, with the vegetable oil thread taking the lead, followed by the sugar, cereal, dairy, and meat thread. The FAO Cereal inflation rate reached 114.4 figures in November, up 2.7 figures $(2.5 \%)$ from October and growing to 19.0 figures $(19.9 \%)$ more than its November 2019 value. The most recent improvement in the index's price was the fifth in a row. The FAO price chart of vegetable oil recorded 121.9 figures in November, up 15.4 figures (or 14.5 percent) from the prior month and reaching its highest possible level since March 2014. The spike is primarily due to ongoing rising prices in palm oil, as well as rises in the value of soy, oilseed rape, and sunflower seed oil. The FAO value of the dairy market measured 105.3 points in November, up 0.9 points $(0.9$ percent $)$ from the preceding period, continuing the upward pattern shown in previous weeks and hitting an 18-month milestone. Higher dairy and cheese prices drove the dramatic rise, which reflected persistent increases in the global trade balance as well as an increase in consumer markets in the world, which coincided with seasonal drops in milk production in the era. The FAO Livestock inflation rate averaged 91.9 points in November, up 0.8 points ( 0.9 percent) from the following month but still 14.6 points (13.7 percent) points in November, up 2.8 points ( 3.3 percent) from October and indicating the second successive below its value in the same month a year earlier year. The FAO Sugar inflation rate reached an 87.5 monthly increase. Stronger new data confirming previous forecasts of global production shortages in the 2020/21 trading season aided the rise in international sugar quotations in November (FAO, 2020). 
Table 1: Global Food Price Fluctuation from September 2020 to November 2020 (FAO, 2020)

\begin{tabular}{ccccc}
\hline $\begin{array}{c}\text { FAO food } \\
\text { price index }\end{array}$ & $\begin{array}{c}\text { Average points in } \\
\text { November 2020 }\end{array}$ & $\begin{array}{c}\text { Increased points from } \\
\text { the previous month }\end{array}$ & $\begin{array}{c}\text { Average points in } \\
\text { October 2020 }\end{array}$ & $\begin{array}{c}\text { Average points in } \\
\text { September 2020 }\end{array}$ \\
\hline Overall Food & 105.0 & $\begin{array}{c}4.0 \\
3.9 \%\end{array}$ & 100.9 & 97.9 \\
\hline Cereals & 114.4 & $\begin{array}{c}2.7 \\
2.5 \%\end{array}$ & 111.7 & 104.0 \\
\hline $\begin{array}{c}\text { Vegetable \& } \\
\text { oil }\end{array}$ & 121.9 & $\begin{array}{c}15.4 \\
14.5 \%\end{array}$ & 106.48 & 104.6 \\
\hline Dairy & 105.3 & $\begin{array}{c}0.9 \\
0.9 \%\end{array}$ & 104.4 & 102.2 \\
\hline Meat & 91.9 & $\begin{array}{c}0.8 \\
0.9 \%\end{array}$ & 91.1 & 91.6 \\
\hline \multirow{2}{*}{ Sugar } & 87.5 & $\begin{array}{c}2.8 \\
3.3 \%\end{array}$ & 85.6 & 79.0 \\
\hline
\end{tabular}

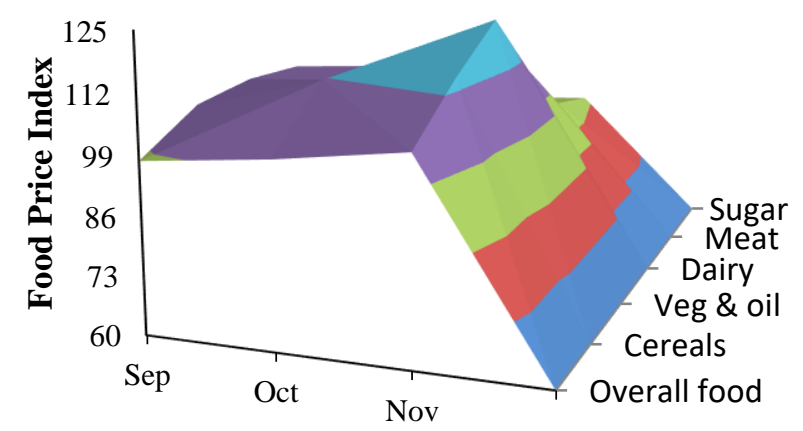

Months

Figure 3: FAO FOOD price index from September 2020 to November 2020 (FAO, 2020)

\section{Food Security Link with Food Price Fluctuation}

"Everyone has a physical and financial right to a plentiful, clean, and balanced meal to meet their nutritional needs and dietary habits at all periods in order to live a productive and balanced life.” believes the World Food Organization (Shaw, 2007)

Food security is very important because it ensures healthy life and maintains good nutritional status. A man is considered food secure when he takes a healthy nutritious diet that in turn increases his metabolism and stamina in daily chores and protects him against many diseases and boosts his growth.

Food security is associated with food price fluctuations in a way that when it is not retained or when food crisis results, then people in the market stockpile staple foods necessary for them to make a living. This ensures good nutritional status and keeps food commodities' prices in moderation. (Prosekov \& Ivanovo, 2018)

Food security is generally considered at three levels, household level (Coleman-Jensen, Gregory, \& Singh, 2014), national and international level. At the national level, food security 
is affected by average per capita energy intake in accordance with the needs of one self. For example, if a person's need is $2000 \mathrm{kcal}$ per day and he is not fulfilling this intake from various food groups, then he will in turn face malnutrition and is the ability to do work in a better manner will decline. At the farm level, food security is seen in the form of good harvesting time, increased fertility rate, by using fertilizers to protect the plants against certain pathogens.

Food security has generally four pillars which are discussed below.

\section{Food Availability}

It indicates the availability of enough food as a result of cultivation, dissemination and exchange. When adequate quality and quantity of food is produced from local agriculture in a certain territory, then that food can meet the nutrient recommendations of its population (Hertel, 2016). One can check food availability through the fertility rate of crops, staple food production rate, and speed of harvesting.

Climate change badly affects food availability. (Brown \& Funk, 2008) When weather is very hot, then the temperature at which crops need to grow changes, so productivity is affected in a sense that one receives the crop too late to transport it to market. Water used to hydrate the crops is irrigated to maintain their moisture content. If weather shocks happen, then land losses it's fertility and land destruction occur as a result.

All these circumstances lead to greater food price hikes. Because when the salesperson does not receive the desired food product as a result of these conditions, they increase food prices to make a living which is then alarming for the rural population. The need is to use fertilizers and water that do not emit harmful nitrous oxide gases that in turn affect the soil fertility and careful measures should be in practice for maintaining crops production (Schoeneberger, 2000). Food availability can be checked through certain food sheets and by surveying the markets.

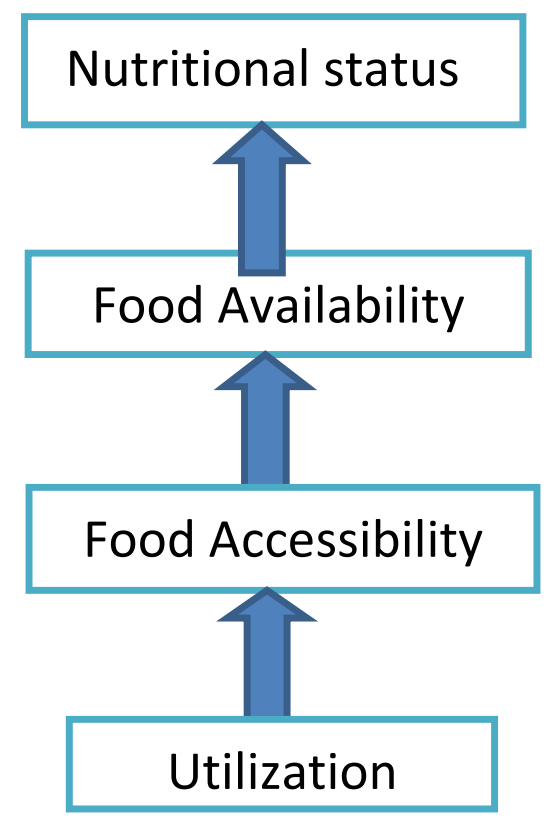

Figure 4: Food and Nutrition Security (Weingarten, 2009) 


\subsection{Access to Food on a Physical and Financial Level}

Another dimension involves income, expenditure, buying capacity of people of that certain area (Rainer Gross, Hans Schoeneberger and Hans Joachim Preuss, 2000). A person with a good income can access the healthy products in the market that fulfill his energy needs and give him the incentive to work properly in daily life. Employment also matters in this scenario. Consider a family who is living hand to mouth to provide food to all members, this family will not be able to buy foods from the four basic food groups and in turn will face hunger, malnutrition, their children will be stunted and underweight.

On the other hand, there is a family with more than average income and its access will be more towards meat, dairy and other food commodities. Their children will be more active able to cope with minor infections and shocks and their nutritional status will be adequate (Leroy, Rule, Frongillo, Harris, \& Ballard, 2015). Poor people whose jobs are street vending, rickshaw drivers, and newspaper sellers, and farmers especially, when they face certain climatic changes like heavy rainfall and temperature change, floods, drought, it becomes more difficult for them to transport their products to the market that results in high food prices. As a result, more people migrate towards cities and towns to make their living and their competition for jobs increases (Mark J Cohen et al, 2010). In the case of weather socks, like floods, famine, crops are destroyed and resultant is increased food prices.

To cope up with this problem, water dams and reservoirs should be made to hold back extra water and to raise shallow groundwater up to a certain level. Transport also matters as people who are far away from supermarkets have to pay more to buy from the supermarket and people who live near retail markets benefit more as they have more access to the market and have to spend less.

\subsection{Food Utilization}

Utilization involves how a person can make the best use of certain vitamins and minerals in the diet (Barney, 1980). It covers intra household food preparation, sanitary facilities, etc. When a person drinks safe water with safe hands, he is protected from many water-borne diseases and when a similar person eats 3 ounces of meat, he can utilize recommended iron and protein present In that meat. On the other side, a person who is not following hygiene and drinks milk with dirty hands or is using unsafe, unpasteurized milk, will not be able to get $300 \mathrm{mg}$ of calcium because his utilization is compromised by certain microbes that got their entry from his hands into that milk. Certain intestinal parasites that got entry from food ingest the food and nutrients present in it and in turn that person remains deficient in such essential nutrients. Diarrheal disease, goiter, food contaminated disorders and stunting all result from unhygienic utilization of food products. The degree to which any individual can fulfill his or her dietary preferences is vital for his or her wellbeing (Von Braun, 2013).

Food should be sufficiently prepared to achieve food safety; meat should be cooked thoroughly and properly packaged and processed. Proper education about sanitation and hygiene can improve the utilization of food and in turn, food prices will be maintained.

\subsection{Stability (Climate Changes)}

Climate change and inflationary pressures have different effects on different aspects of food safety. Climate instability affects the food production stability factor by affecting livestock and crop production. Climate variability also has an effect on relative production and input 
prices, which has an indirect impact on food security (Hertel, Burke, \& Lobell, 2010; Wheeler \& Von Braun, 2013). Climate change and inflationary pressures have different effects on different aspects of food security. Climate instability affects the food production stability factor by affecting livestock and crop production. Climate variability also has an effect on relative production and input prices, which has an indirect impact on food security (Wossen, Berger, Haile, \& Troost, 2018) The effect on food security of climate-induced shifts in food prices is however not always negative. High agricultural product costs are projected to result in a better supply response, with farmers obtaining more land and several other inputs to the rural activities, as well as additional production to boost crop yields (Farooq, 2014). However, a rise in price inflation, particularly in recent years, has been linked to greater price volatility.

Climate change impacts food security stability as severe weather events reduce crop yields or damage physical infrastructure, resulting in reduced food supply and driving food price shocks, reducing food access (Wheeler and Braun, 2013). Bio-energy policies are also thought to have contributed to food price instability as mitigation attempts to tackle climate change (Wheeler and Braun, 2013)

\section{Causes of Increased Food Prices}

Agricultural commodity prices have also been volatile in recent years, putting both buyers and producers on edge (Huka, Ruoja, \& Mchopa, 2014). The United Nations' Food and Agriculture Organization (FAO) estimates that the food inflation figures have fluctuated dramatically throughout the last four years. According to the indicator, the value rose from 122 in 2006 to 214 in June 2008. This was attributed to factors such as transportation costs, agricultural production, food inventory level as stock levels drop, increased prices, change in the exchange rate of leading export countries in general, import tariffs, famine, low innovation, and food production as minor supply shocks can trigger significant price changes. The agricultural commodity markets have gradually undergone enormous price instability, as per the Global Market Survey (2007), and production and consumption factors such as population expansion and wind patterns are the main reasons for these shifts (Huka et al., 2014).

Since 2007, extreme price volatility has become more common in agricultural trade flows, causing severe supply issues in some cases, particularly in developing countries. The study aimed to identify the multiple reasons for price instability in agricultural products on this framework. 


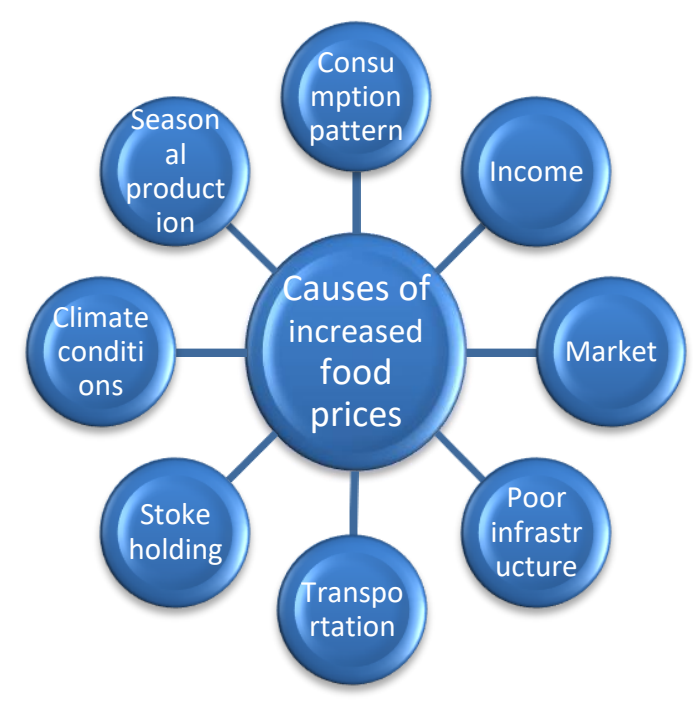

Figure 5: Diagram showing causes of food products price inflation (Timmer, 2008)

\subsection{Consumption Pattern}

Food prices are a key indicator of consumption habits, and rising food prices, particularly for the poor, can have dire implications for nutritional factors and performance. The degree to which allowed output and consumption shocks convert into market volatility is determined by production and consumption elasticity, which reflects producers' and consumers' susceptibility to price changes. Recent developments in the food trade show drastic changes in food consumption trends, throughout the world. These developments are expected to grow during the forecast period. Many of these changing consumer habits are influenced by a number of variables, but economic growth is perhaps the most prominent. (Haq, Arshid, \& Anwar, 2009). Sales growth has led to increased consumer purchasing power across the world. Over the years, prompting consumption to shift to more expensive ingredients (Seale Jr, Regmi, \& Bernstein, 2003)

Table 2: Distribution of expenditure shares for food sub-categories around Countries in 2017 (Poterba, 2017).

\begin{tabular}{llll}
\hline Food Groups & Low wage family & Middle wage family & High wage family \\
\hline Cereals & 26.93 & 17.98 & 11.83 \\
\hline Veg \& Fruits & 20.37 & 18.24 & 14.62 \\
\hline Meat & 19.65 & 22.48 & 25.92 \\
\hline Dairy & 7.89 & 10.78 & 10.03 \\
\hline Beverages & 9.25 & 14.22 & 25.92 \\
\hline Fats \& Oil & 5.90 & 4.36 & 2.78 \\
\hline Other Foods & 10.0 & 11.94 & 11.41 \\
\hline Total food expenditure & 52.58 & 34.69 & 16.97 \\
\hline
\end{tabular}

Population increase and economic growth have been followed by a dietary transition (Popkin, 1994). Budget surplus allows for the buying of relatively high processed goods like dairy and meat. Pakistan has made substantial progress by improving the levels of all major food items, like grains, meat, milk, sugar, and eggs, per unit over time (Cohen \& Garrett, 2010). As a result, per capita, calorie consumption increased from 2078 in 1949-50 to 2450 in 2012-13. Protein and fats patterns that are similar have been discovered In Pakistan, Haq et al (2008) and Friedman, Hong, and Xiaohui (2011) reported compensating variance to estimate the magnitude of welfare losses due to rising commodity prices. Since 2006-07, the rates of most 
food products in Pakistan have risen by far more than 100 percent (Malik, Nazli, \& Whitney, 2015).

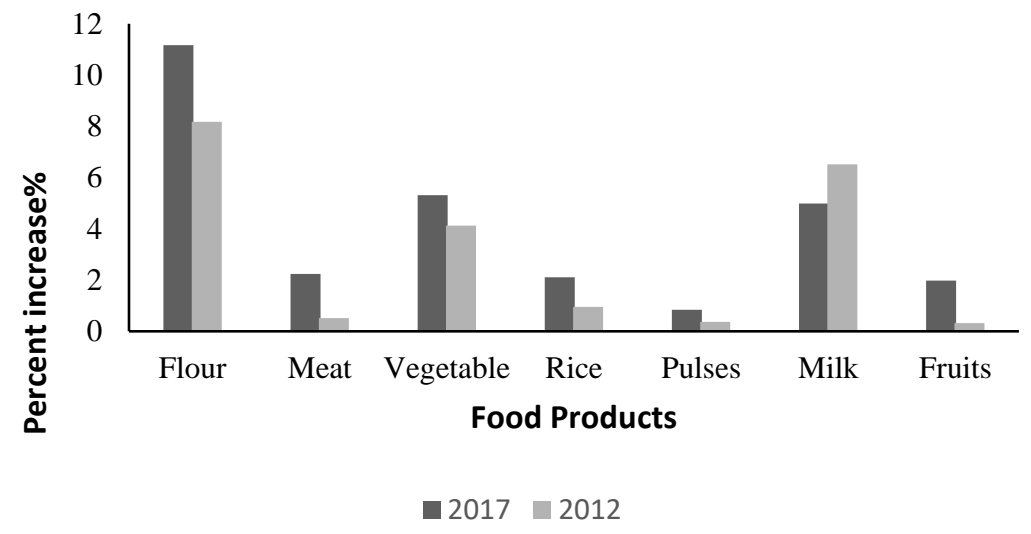

Figure 6: Per capita consumption of food in Pakistan 2012-2017 (Karim \& Ibrahim, 2018)

\subsection{Income}

Climate change and increased food price volatility greatly impact household income and employment impacts are highly negative for poor households and seem to be more at risk. Due to the extreme unpredictability, dissection, and degradation of purchasing power, food exchange rates are of greater importance and consideration than high energy prices. Food market volatility has an indirect impact on personal domestics and their necessities.

Oil is a vital supply of fuel that is used in both industrial and agricultural development. The oil market is a crucial procedure that affects their everyday suitable approach. In the second half of 2013, there was an unanticipated price increase in global improves the financial. The oil price fell to a new low of USD 28 per barrel, down from a high of USD 100 per barrel in 2012. Oil-producing countries that depend heavily on oil trade for financial development face a serious threat to their growth rate and income distribution. Another benefit for oil-importing countries is that it acts as a motivation or cost-cutting measure. However, a drop in oilexporting countries' revenues due to a sharp drop in oil prices results in low wages, low financing, limited efficiency, and, as a consequence, high commodity prices, especially for food items, which account for about $30 \%$ of family income in these regions. Increased food instability in Ethiopia and Ghana resulted in a two-fold rise in the price of agricultural goods such as cereals and sorghum, and a 150 percent change in the cost of maize, putting poor households at risk, with $29.6 \%$ of the poverty rate. (Ding Chen1, Czech, 66, 2020)

Following data of OCT 2017 indicates daily per capita income average value and oil output (Ding Chen1, Czech, 66, 2020)

Table 3: October 2017 data of average per capita income value and oil output.

\begin{tabular}{llllllll}
\hline $\begin{array}{l}\text { Sr } \\
\text { no }\end{array}$ & Region & Country & $\begin{array}{l}\text { Reserve } \\
(\mathbf{m b} / \mathbf{d})\end{array}$ & $\begin{array}{l}\text { GDP } \\
\text { (Billion } \\
\text { USD) }\end{array}$ & $\begin{array}{l}\text { PPP } \\
\text { (Thousand } \\
\text { USD) }\end{array}$ & $\begin{array}{l}\text { Oil } \\
\text { output } \\
(\mathbf{m b} / \mathbf{d}) *\end{array}$ & $\begin{array}{l}\text { Countries income } \\
\text { status }\end{array}$ \\
\hline 1 & $\begin{array}{l}\text { Middle } \\
\text { east }\end{array}$ & Iran & 157530 & 14.00 & 11666 & 3.90 & Low \\
\hline 2 & Africa & Gabon & 2000 & 514 & 7453 & 0.21 & Low \\
\hline 3 & US & Venezuela & 299953 & 381 & 12846 & 2.30 & High \\
\hline 4 & Africa & Nigeria & 37070 & 263 & 2344 & 1.90 & Low \\
\hline
\end{tabular}




\begin{tabular}{llllllll}
\hline 5 & $\begin{array}{l}\text { Middle } \\
\text { east }\end{array}$ & $\begin{array}{l}\text { Saudi } \\
\text { ARABIA }\end{array}$ & 266578 & 711 & 22939 & 10.4 & High \\
\hline
\end{tabular}

In a census of five African nations, Asia, and Latin America, urban nonworking, such as wage stagnation, was found to be $10 \%$ or less; strong, but not alarmingly so. Street vendors, rickshaw drivers, manual labor, and manufacturing are examples of civilian inadequate jobs that are normal, fearful, terrible, and low-paying. That vulnerable people are dedicated to their employees and cannot switch jobs nearly every day, and that their work is irreversible. Surprisingly, climate change-induced high food instability has an effect on civilian wages in the same way as it has on farm households. Many workers are unable to work due to the rain, and getting goods from cities becomes challenging. Factories need fewer workers across seasonal transition times, resulting in large variations that affect both rural and urban families, with the poor becoming more likely to experience poverty (Garrett, 2010).

\subsection{Market}

Changes in global grain prices continue to be important, with correlations of variance of about $20 \%-30 \%$ for wheat, rice, and white maize. Changes in global grain prices continue to be important, with correlations of variance of about $20 \%-30 \%$ for wheat, rice, and white maize. Although there is no evidence that price volatility has risen (prices were most volatile in the 1970s), there is uncertainty that changes in global markets, especially commodity depletion by leading economies (China, the United States, and the European Union) and rapid commodity prices in Asia, could lead to higher and more volatile prices over time. Agricultural exports for wheat and maize in importing countries have generally been higher than global markets in household food markets, indicating retract costs in converting global prices into domestic markets, as well as policy infringements that separate domestic markets from world demand. The shakiness of household prices appears to be highest in Africa, especially in landlocked countries. Because of an increase in transportation costs and weak market facilities, the income gap between export and import finance is widening. Household shocks are amplified by the high trade financing balance, which is coupled with high domestic demand variability. (Derek Byerlee a, 2006)

In recent decades, the balance of import and export deposits in Ethiopia has enabled maize prices in Addis Ababa to fluctuate between about US\$ 50 and billion Dollars 250 per ton. Rice export prices have fallen from a high of US\$ 340 per ton in 1996 to a low of US\$ 170 per ton in 2001, before rebounding to over US\$300 per ton in 2005.

Policymakers should understand the reason food prices increase import parity and should form plans and strategies to protect the urban and rural welfare with respect to shortfalls in food production and food crisis for the promotion of political and social stability and certain policy options should be adopted for avoiding food crisis in future. (Derek Byerlee a, 2006)

\subsection{Stockholding}

The accumulation of stock is the source of instability. When stocks are plentiful, small generation or consumption shocks can have a large cost effect, but while they are scarce, the reverse is true. Furthermore, once stock levels have gotten to be high, they will remain high until utilization has improved output for a long enough period to retain the previous overabundance. In the event when supply and demand stuns are autonomous over time, stockholding consists of a patterned nature in costs and inconsistencies. By 2006, world grain commodities had fallen to lower levels, which is also attributed to one of the causes of later 
high grain price volatility. Since stock changes take time, volatility levels may remain high for a while longer. However, this does not imply that instabilities will always be higher. Other factors can also play a role in opening up or worsening instability. So long as inventory is accumulated through times of overabundance demand, stockholding can reduce volatility. (Morgan, Has food price volatility risen? , 2010)

Other factors can also play a role in exacerbating or restricting instability. As stocks are accumulated in times of excess supply and released in times of abundance demand, stockholding can reduce volatility and extend Stockholding, on the other hand, is more conservative in reducing the degree of value falls during abundant inventory stuns (abundant harvests) than in reducing the level of cost rises during shortages, since destocking is dependent on the availability of holdover products from the context. As a result, stockholding reduces uncertainty and gives the price structure a more positive appearance. The assumption may be a pivotal figure that influences volatility in either a superficial way. Physical stockholding, buy-and-sell trades of product possibilities, and other subsidiary contracts are all examples of theory. Nonetheless, some futures market commitments are theoretical - the traditional administrative distillation figure, which can have a substantial impact on volatility. - the traditional directorial distinction between endorsing, in which supply service providers struggle to the mitigated chance presentation by prospects exchanges, and conjecture, in which inspectors are "non-commercials," i.e. they have no interest in the product service exchange. Product potential merchandise appears to have a mechanism in which risk is transferred from industrial to non-commercial merchants, i.e. from producers to examiners. Examiners offer the compensation of import and export by embracing this cost risk, allowing producers to find opposite groups in a relatively low-cost manner. (Morgan, 2010)

\section{Impact of Price Fluctuation at the Individual Level:}

An increase in food prices results in hungrier people. In 2006, the FAO estimated that 815 million people were and there is an increase of 75-135million people with increased vulnerability and the risk of food insecurity is 1 billion people. In developing countries, people are more vulnerable to hunger because of shocks in macroeconomics (Darnton, 2009).

Maternal and child nutrition is affected due to these changes and mainly due to an increase in micronutrient deficiencies and reduction in dietary quality furthermore morbidity and mortality of infectious diseases have also been increased. Underweight and wasting of the child has also been increased because of reduction in the quantity of food. Undernutrition at 2 years of age can lead to long-term effects and hence a slight change in the price of foods can lead to life-long disorders. Population groups most affected by increased price are lactating women, pregnant women, children and chronically ill people including HIV/AIDS and tuberculosis. (Henk-jan Brinkman, 2010).

\section{Conclusion}

The study concluded that there are four factors associated with price fluctuation including food supply, economic and physical access to food, able to access food, and economic stability. Moreover, some causes that directly show an impact on the global market are consumption patterns, family income and market values. Prices of grains become high because of seasonal fluctuations. Price fluctuation mostly affects poor people and most vulnerable groups include pregnant women, children, people with diseases etc. several short term and long-term policies are made to cope up with this problem that includes different 
programs globally. But these policies should be implemented in better ways to maintain food prices stability and overall consumer

\section{References}

Barney, G. O. (1980). The Global 2000 Report to the President--entering the Twenty-first Century: The technical report (Vol. 2). US Government Printing Office.

Brinkman, H. J., De Pee, S., Sanogo, I., Subran, L., \& Bloem, M. W. (2010). High food prices and the global financial crisis have reduced access to nutritious food and worsened nutritional status and health. The Journal of nutrition, 140(1), 153S-161S.

Brown, M. E., \& Funk, C. C. (2008). Food security under climate change.

Byerlee, D., Jayne, T. S., \& Myers, R. J. (2006). Managing food price risks and instability in a liberalizing market environment: Overview and policy options. Food Policy, 31(4), 275-287.

Cohen, M. J., \& Garrett, J. L. (2010). The food price crisis and urban food (in) security. Environment and Urbanization, 22(2), 467-482.

Coleman-Jensen, A., Gregory, C., \& Singh, A. (2014). Household food security in the United States in 2013. USDA-ERS Economic Research Report, (173).

Darnton-Hill, I., \& Cogill, B. (2010). Maternal and young child nutrition adversely affected by external shocks such as increasing global food prices. The Journal of nutrition, 140(1), 162S-169S.

Ding, C., Gummi, U. M., Lu, S. B., \& Muazu, A. (2020). Modelling the impact of oil price fluctuations on food price in high and low-income oil exporting countries. Agricultural Economics, 66(10), 458-468.

FAO. (2018). Food Price Index. World food situation. Report of Food and Agriculture organization. Rome.

FAO. (2020). FAO Food Price Index rises sharply. Report of Food and Agriculture organization. Rome.

Farooq, O. (2014). Pakistan Economic Survey 2013-14, Agriculture. Economic Advisory Wing, Ministry Finance, Government of Pakistan, Islamabad.

Morgan, C. W., \& Gilbert, C. L. (2010, January). Has food price volatility risen. In Technological Studies Workshop on Methods to Analyse Price Volatility. Seville (pp. 28-29).

Gross, R., Schoeneberger, H., Pfeifer, H., \& Preuss, H. J. (2000). The four dimensions of food and nutrition security: definitions and concepts. SCN News, 20(20), 20-25.

Haq, R., Arshid, N., \& Anwar, T. (2009). Inequality and welfare by food expenditure components. The Pakistan Development Review, 755-768.

Hertel, T. W. (2016). Food security under climate change. Nature Climate Change, 6(1), 1013.

Hertel, T. W., Burke, M. B., \& Lobell, D. B. (2010). The poverty implications of climateinduced crop yield changes by 2030. Global Environmental Change, 20(4), 577-585.

Huka, H., Ruoja, C., \& Mchopa, A. (2014). Price fluctuation of agricultural products and its impact on small scale farmers development: Case analysis from Kilimanjaro Tanzania.

Karim, R., Khan, S., \& Ibrahim, M. Nasrullah (2018) Estimation of Per Capita Food Consumption Patterns and Related Poverty in Kabal. Bus Eco J, 9(357), 2.

Leroy, J. L., Ruel, M., Frongillo, E. A., Harris, J., \& Ballard, T. J. (2015). Measuring the food access dimension of food security: a critical review and mapping of indicators. Food and nutrition bulletin, 36(2), 167-195.

Malik, S. J., Nazli, H., \& Whitney, E. (2015). Food consumption patterns and implications for poverty reduction in Pakistan. The Pakistan Development Review, 651-669. 
Popkin, B. M. (1994). The nutrition transition in low-income countries: an emerging crisis. Nutrition reviews, 52(9), 285-298.

Poterba, J. M. (2017). Is the gasoline tax regressive? (pp. 31-50). Routledge.

Prosekov, A. Y., \& Ivanova, S. A. (2018). Food security: The challenge of the present. Geoforum, 91, 73-77.

Seale Jr, J. L., Regmi, A., \& Bernstein, J. (2003). International evidence on food consumption patterns (No. 1488-2016-123508).

Shaw, D. J. (2007). World Food Summit, 1996. In World Food Security (pp. 347-360). Palgrave Macmillan, London.

Timmer, C. P. (2008). Causes of high food prices (No. 128). ADB Economics Working Paper Series.

Weingärtner, L. (2009). The concept of food and nutrition security. Achieving Food and Nutrition Security, 3, 21-52.

Wheeler, T., \& Von Braun, J. (2013). Climate change impacts on global food security. Science, 341(6145), 508-513.

Wossen, T., Berger, T., Haile, M. G., \& Troost, C. (2018). Impacts of climate variability and food price volatility on household income and food security of farm households in East and West Africa. Agricultural systems, 163, 7-15. 